\title{
IDENTIFICATION, CLASSIFICATION AND VALORIZATION OF TOURIST MOTIVES OF THETH (THETH) VALLEY
}

\author{
Qerim Kastrati $^{1}$
}

\begin{abstract}
The subject of this scientific work is the identification, classification and valorization of tourist motives of Theth Valley and their spatial distribution. Executed valorisation of tourist motives of Theth Valley and finding their real value with the purpose is based on the scientific assumption that in the Theth Valley there are insufficiently explored tourist motifs that have a high tourism value and that the scientific process of identification and valorization would raise the competitiveness of tourism in this region. In the implementation of the set of scientific research objectives were realized the following tasks:analysis of available literature and cartographic data and theoretical identification and classification of tourist motives, field observations and collection of additional data and accompying photo documentation. Several methods were used, such as analysis and synthesis, comparative, descriptive statistical, UNWTO method, the method of „Interpersonal consent" and others. On the Theth Valley were identified 29 tourism motives. With the procedure of tourist and geographical evaluation the Theth Valley has an overall tourism value of 4.30 and is ranked in the motives of national tourist interest. This region offers very good conditions for the development of these forms of tourism: mass winter tourism, eco-tourism, sightseeing and recreational tourism, hiking, hunting, health tourism and others. Tourist valorization in the Valley of Theth, shows that all the analyzed values of tourist motives are unique, and its uniqueness and attractiveness have a national character with high value for uniqueness and attractiveness, the ambience and the possibility of using motives for tourism purposes and others. The results of this work will lead to raising awareness on the preservation of these motifs in order to improve conditions for the development of cultural tourism in this region, and create the already rich tourist offer and also promote the heritage and indigenous culture in this region.
\end{abstract}

Key words: identification, classification and valorization, Theth.

\section{INTRODUCTION}

The subject of research - The subject of this scientific paper is the identification, classification and valorization of tourist motives of Theth Valley and their spatial distribution.On these grounds is carried out the valorization of tourist motives of Theth Valley and established their real tourist value for the purpose of applications for tourist offer. A concise presentation of the most valuable natural and anthropogenic tourist motives of Theth Valley in the best way confirms the importance of this research for better and more rational use for tourism purposes.

The hypothesis, objective and research topics - Hypothesis of this paper is based on the scientific assumption that in the Theth Valley there are insufficiently explored

\footnotetext{
${ }^{1} \mathrm{PhD}$, Ministry of Education, Science and Technology, Malisevo, Kosovo. e-mail: qerimkastrati@yahoo.com
} 
tourist motifs that have a high tourism value and that through the scientific process of identification and evaluation would raise the competitiveness of the tourism of the area. The aim of this paper is to study the quantitative and qualitative characteristics of the social and geographical tourism motives of the Theth Valley, and analysis of their value for the organization and promotion of tourism. In the implementation of the set of scientific research were realized the following tasks:analysis of available literature and cartographic data and theoretical identification and classification of tourist motives, field observation and collecting additional data and accompanying photo documentation, determination and classification of the most valuable tourist attractiveness in order to optimize the tourism offer as a real basis for planning the development of tourism and complementary activities that make support tourism.

The methodology of scientific research - for the purposes of this research were used more general and special scientific research methods, such as analysis and synthesis, abstraction and concretization, generalization and specialization, comparative, descriptive, statistical, combined qualitative-quantitative comparative method, UNWTO classification methods, methods of representative sampling and methods of spatial clustering (cluster analysis), Method „Interpersonal consent“ and others. The selection of relevant parameters, which are applied in the valuation of art tourist motives of the Cursed Mountains listed in the tables using the value scale 0-5;

Through the method classification the motives are classified as more of the following hierarchy ranks: L, R, N and $\mathrm{M}$. In this research was used the evaluation model of analyzed the natural-geographical and socio-geographical tourism motives in the area of the Cursed Mountains, by applying scientific defined parameters for each group of motifs, respectively. To value the natual tourist motifs were used 8 parameters, and to value the tourist anthropogenic motifs were used 11 parameters. From the point of the comparison the results of the evaluation is applied the comparative method to several relevant parameters, such as: the degree of attractiveness, advantage of geographical position, distance and spatial connection with emissive areas.

\section{IDENTIFIED TOURISM MOTIFS OF THETH VALLEY}

In the process of identification of tourist motives of the Theth Valley, was consulted, preliminary, relevant tourist-geographic and all other written literature (studies, press articles, tourist projects, brochures, etc.). During the drafting process were consulted the experts dealing with tourism and geography concerning the region of the Cursed Mountains, also many interviews were carried with officials from relevenat institutions of Albania, dealing with tourism, also many field research were conducted and local residents were interviewed, on the basis of which it was possible to prove the facts about the tourist motives in the area of the Theth Valley. During field research in the process of identification, in addition, were made the surveys with the local population and formed fund notes and photos, which served as the basis for making a list/register of identified tourist motives of the Theth Valley and defining their tourism value in the 
later stage of the research, the result of which is a list/register of valuable tourist motives of the Theth Valley.

\section{EVALUATION OF TOURIST MOTIVES OF THE THETH VALLEY}

The tourist motives if the Theth Valley are very diverse, whose number is 29, which means that there are 29 tourist motives or 4.24 , tourist motives in $1 \mathrm{~km}^{2}$. According to the genesis, they are divided into two basic groups:

- Natural tourist motives which includes 17 tourist motives and

- Anthropogenic tourist motives which includes 12 tourist motives.

To determine the actual tourism value of the identified tourist motives of the Theth Valley, on the basis of the obtained values of 11 parameters, we used the following quantifiers: general tourist value, individual tourist value and the total value of tourism.

Table 1. Registry of identified, valuated and ranking of natural tourist motives of the Theth Valley according to genetic type.

\begin{tabular}{|c|c|c|c|c|c|c|c|c|c|c|}
\hline & 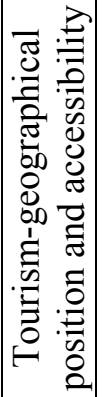 & 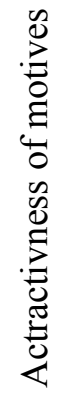 & 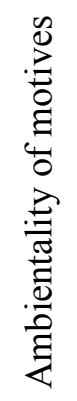 & 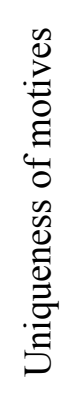 & 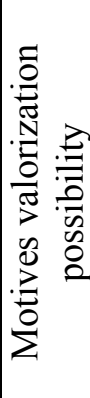 & 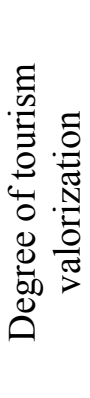 & 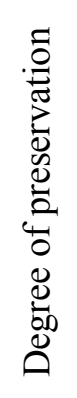 & 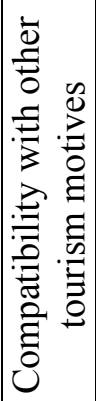 & 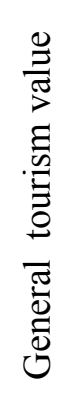 & 光 \\
\hline \multicolumn{11}{|l|}{$\begin{array}{l}\text { 1.GEOMORPHOLOGICAL } \\
\text { MOTIVES }\end{array}$} \\
\hline \multicolumn{11}{|l|}{ 1.1.MOUNTAIN PEAKS } \\
\hline Jezerce's Peak; 2694 m; & 0.50 & 3.10 & 4.50 & 5.00 & 4.10 & 2.80 & 4.10 & 4.10 & 3.53 & $\mathbf{N}$ \\
\hline Papluka's Peak; 2569 m; & 0.50 & 2.30 & 3.10 & 4.10 & 3.20 & 2.30 & 3.90 & 3.90 & 2.91 & $\mathbf{R}$ \\
\hline Sheniku Peak; 2553 m; & 1.00 & 2.60 & 3.00 & 1.30 & 3.30 & 2.30 & 4.10 & 4.10 & 2.71 & $\mathbf{R}$ \\
\hline Radohina Peak; 2568 m; & 0.50 & 2.90 & 3.00 & 4.10 & 3.30 & 2.30 & 3.90 & 3.90 & 2.99 & $\mathbf{R}$ \\
\hline Harapi Peak; 2217 m; & 0.70 & 2.90 & 3.90 & 4.10 & 3.90 & 2.70 & 4.20 & 3.90 & 3.29 & $\mathbf{R}$ \\
\hline Bosh`s Peak; 2416 m; & 1.00 & 3.10 & 4.60 & 4.30 & 4.10 & 2.90 & 4.50 & 4.10 & 3.58 & $\mathbf{N}$ \\
\hline Dry Peak; 2541 m; & 0.50 & 2.10 & 2.90 & 4.10 & 3.10 & 2.30 & 3.90 & 3.60 & 2.81 & $\mathbf{R}$ \\
\hline $\begin{array}{l}\text { The average tourist value of } \\
\text { mountain peaks }\end{array}$ & 0.67 & 2.71 & 3.57 & 3.86 & 3.57 & 2.51 & 4.09 & 3.94 & 3.12 & $\mathbf{R}$ \\
\hline \multicolumn{11}{|l|}{ 1.3. RIVER VALLEY } \\
\hline Thethi Valley & 1.70 & 5.00 & 5.00 & 5.00 & 5.00 & 2.70 & 5.00 & 5.00 & 4.30 & $\mathbf{N}$ \\
\hline $\begin{array}{l}\text { The average tourist value of } \\
\text { river valley }\end{array}$ & 1.70 & 5.00 & 5.00 & 5.00 & 5.00 & 2.70 & $\mathbf{5 . 0 0}$ & 5.00 & 4.30 & $\mathbf{N}$ \\
\hline \multicolumn{11}{|l|}{ 1.6. MOUNTAIN PASSES } \\
\hline Thorës pass & 2.00 & 3.70 & 3.80 & 3.90 & 3.90 & 2.90 & 4.10 & 3.90 & 3.53 & $\mathbf{N}$ \\
\hline
\end{tabular}




\begin{tabular}{|c|c|c|c|c|c|c|c|c|c|c|}
\hline Peja pass & 1.20 & 2.90 & 3.90 & 4.10 & 3.80 & 1.70 & 4.10 & 3.50 & 3.15 & $\mathbf{R}$ \\
\hline Jezercë pass & 0.60 & 2.10 & 3.70 & 4.10 & 3.80 & 1.70 & 4.10 & 3.30 & 2.93 & $\mathbf{R}$ \\
\hline Valbona pass & 1.80 & 2.90 & 3.90 & 4.00 & 3.90 & 2.00 & 4.00 & 3.70 & 3.28 & $\mathbf{R}$ \\
\hline $\begin{array}{l}\text { Average tourist assessment } \\
\text { of mountain passes }\end{array}$ & 1.40 & 2.90 & 3.83 & 4.03 & 3.85 & 2.08 & 4.08 & 3.60 & 3.22 & $\mathbf{R}$ \\
\hline $\begin{array}{l}\text { GENERAL ASSESSMENT } \\
\text { OF TOURIST } \\
\text { GEOMORPHOLOGICAL } \\
\text { MOTIVES }\end{array}$ & 1.26 & 3.54 & 4.13 & 4.29 & 4.14 & 2.43 & 4.39 & 4.18 & 3.54 & $\mathbf{R}$ \\
\hline \multicolumn{11}{|l|}{ 2.CLIMATIC MOTIFS } \\
\hline \multicolumn{11}{|l|}{$\begin{array}{l}\text { 2.1.LOCALITIES OF } \\
\text { TYPICAL } \\
\text { MOUNTANIOUS } \\
\text { CLIMATE } \\
\end{array}$} \\
\hline $\begin{array}{l}\text { The space of Qerem; Sea } \\
\text { Level .900-1800 m, }\end{array}$ & 1.90 & 4.70 & 4.70 & 4.50 & 4.80 & 1.70 & 3.90 & 4.10 & 3.79 & $\mathbf{N}$ \\
\hline $\begin{array}{l}\text { Average tourist assessment of } \\
\text { motifs of mountainous } \\
\text { climate }\end{array}$ & 1.90 & 4.70 & 4.70 & 4.50 & 4.80 & 1.70 & 3.90 & 4.10 & 3.79 & $\mathbf{N}$ \\
\hline \multicolumn{11}{|l|}{$\begin{array}{l}\text { 3. HYDROGEOGRAPHIC } \\
\text { MOTIFS }\end{array}$} \\
\hline \multicolumn{11}{|l|}{$\begin{array}{l}\text { 3.1. Water spings- Fountain- } \\
\text { heads }\end{array}$} \\
\hline Water source of Syri & 1.80 & 3.10 & 4.10 & 4.10 & 3.10 & 1.90 & 3.70 & 3.60 & 3.18 & $\mathbf{R}$ \\
\hline Water sources of Okol & 1.90 & 3.10 & 3.90 & 3.60 & 4.10 & 1.80 & 3.80 & 3.80 & 3.25 & $\mathbf{R}$ \\
\hline $\begin{array}{l}\text { Average tourist assessment } \\
\text { of water sources- Fountain- } \\
\text { heads }\end{array}$ & 1.85 & 3.10 & 4.00 & 3.85 & 3.60 & 1.85 & 3.75 & 3.70 & 3.21 & $\mathbf{R}$ \\
\hline \multicolumn{11}{|l|}{ 3.2.RIVERS } \\
\hline River of Theth & 2.10 & 4.10 & 4.80 & 4.80 & 4.80 & 2.10 & 3.90 & 4.10 & 3.84 & $\mathbf{N}$ \\
\hline $\begin{array}{l}\text { Average tourist assessment of } \\
\text { rivers }\end{array}$ & 2.10 & 4.10 & 4.80 & 4.80 & 4.80 & 2.10 & 3.90 & 4.10 & 3.84 & $N$ \\
\hline \multicolumn{11}{|l|}{ 3.3.WATERFALLS } \\
\hline Waterfalls of Grunas & 2.20 & 5.00 & 4.80 & 4.90 & 4.90 & 2.80 & 4.60 & 4.90 & 4.26 & $\mathbf{N}$ \\
\hline $\begin{array}{l}\text { Average tourist assessment of } \\
\text { waterfalls }\end{array}$ & 2.20 & 5.00 & 4.80 & 4.90 & 4.90 & 2.80 & 4.60 & 4.90 & 4.26 & $\mathbf{R}$ \\
\hline $\begin{array}{l}\text { GENERAL ASSESSMENT } \\
\text { OF TOURIST } \\
\text { HYDROGEOGRAFIC } \\
\text { MOTIFS }\end{array}$ & 2.05 & 4.07 & 4.53 & 4.52 & 4.43 & 2.25 & 4.08 & 4.23 & 3.77 & $\mathbf{N}$ \\
\hline \multicolumn{11}{|l|}{$\begin{array}{l}\text { 4. BIOGEOGRAPHIC } \\
\text { MOTFIS }\end{array}$} \\
\hline \multicolumn{11}{|l|}{$\begin{array}{l}\text { 4.1. BIOGEOGRAFIC } \\
\text { LOCALITIES OF } \\
\text { MOUNTAIN CLIMATE }\end{array}$} \\
\hline $\begin{array}{l}\text { Biogeographic locality of } \\
\text { mountainious climate of } \\
\text { valley of Theth } 700 \text { do } \\
1.800 \mathrm{~m} \text {; }\end{array}$ & 1.90 & 3.90 & 4.60 & 4.10 & 4.00 & 1.70 & 4.30 & 3.90 & 3.55 & $\mathbf{N}$ \\
\hline $\begin{array}{l}\text { Averge tourist assessment of } \\
\text { localities of mountanious } \\
\text { climate }\end{array}$ & 1.90 & 3.90 & 4.60 & 4.10 & 4.00 & 1.70 & 4.30 & 3.90 & 3.55 & $\mathbf{N}$ \\
\hline $\begin{array}{l}\text { GENERAL ASSESSMENT } \\
\text { OF TOURIST OF } \\
\text { NATURAL MOTIFS }\end{array}$ & 1.78 & 4.05 & 4.49 & 4.35 & 4.34 & 2.02 & 4.17 & 4.10 & 3.66 & $\mathbf{N}$ \\
\hline
\end{tabular}


Table 2. Registry of identified, valuated and ranking of anthropogenic tourist motives of the Theth Valley according to genetic type.

\begin{tabular}{|c|c|c|c|c|c|c|c|c|c|c|c|c|c|}
\hline & 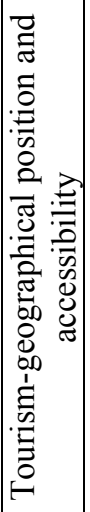 & 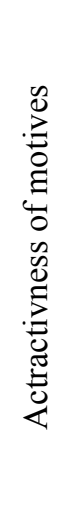 & 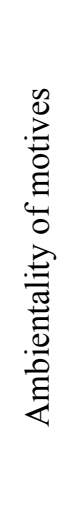 & 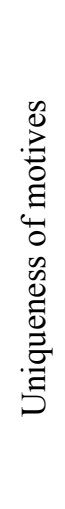 & 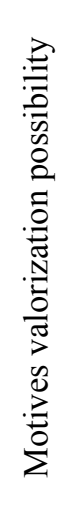 & 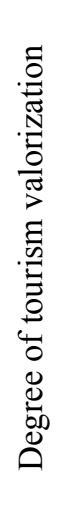 & 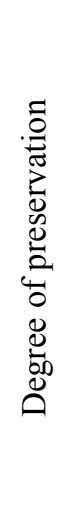 & 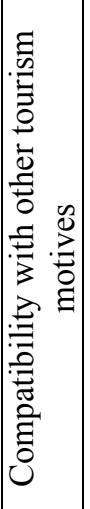 & 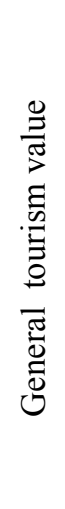 & 䒕 & 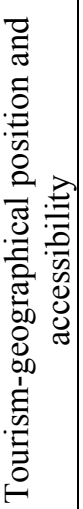 & 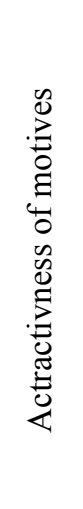 & 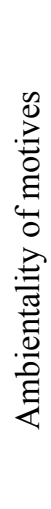 \\
\hline \multicolumn{14}{|l|}{$\begin{array}{c}\text { 5.CULTURAL } \\
\text { AND } \\
\text { HISTORICAL } \\
\text { MOTIVES }\end{array}$} \\
\hline \multicolumn{14}{|l|}{ 1.2. CHURCH } \\
\hline $\begin{array}{l}\text { Catholic church - } \\
\text { Theth; }\end{array}$ & 3.6 & 3.3 & 3.9 & 3.6 & 3.7 & 3.9 & 3.9 & 3.9 & 3.1 & 4.2 & 3.8 & 3.72 & $\mathbf{N}$ \\
\hline $\begin{array}{l}\text { Averge tourist } \\
\text { assessment of } \\
\text { churches }\end{array}$ & 3.6 & 3.3 & 3.9 & 3.6 & 3.7 & 3.9 & 3.9 & 3.9 & 3.1 & 4.2 & 3.8 & 3.72 & $N$ \\
\hline \multicolumn{14}{|l|}{ 1.3.TOWERS } \\
\hline $\begin{array}{l}\text { Shutting Tower - } \\
\text { Theth }\end{array}$ & 1.9 & 3.9 & 3.5 & 4.1 & 3.9 & 4.8 & 3.8 & 3.9 & 3.9 & 3.9 & 4.1 & 3.79 & $\mathbf{N}$ \\
\hline $\begin{array}{l}\text { Tower of Lulash } \\
\text { Kecit - Theth; }\end{array}$ & 1.9 & 3.4 & 3.5 & 3.1 & 3.3 & 4.1 & 3.4 & 3.7 & 2.9 & 3.6 & 3.5 & 3.31 & $\mathbf{R}$ \\
\hline \multicolumn{14}{|l|}{ watermill/Theth } \\
\hline $\begin{array}{l}\text { Averge tourist } \\
\text { assessment of towers }\end{array}$ & 1.9 & 3.6 & 3.5 & 3.6 & 3.6 & 4.4 & 3.6 & 3.8 & 3.4 & 3.7 & 3.0 & 3.55 & $N$ \\
\hline $\begin{array}{l}\text { GENERALASSESS } \\
\text { MENT } \\
\text { OFTOURISTOFCU } \\
\text { LTURAL } \\
\text { ANDHISTORICAL } \\
\text { MOTIFS }\end{array}$ & 2.7 & 3.5 & 3.7 & 3.6 & 3.6 & 4.1 & 3.7 & 3.8 & 3.2 & 3.9 & 3. & 3.63 & $\mathbf{N}$ \\
\hline \multicolumn{14}{|l|}{$\begin{array}{c}\text { 2. ARTISTIC } \\
\text { MOTIVES }\end{array}$} \\
\hline \multicolumn{14}{|l|}{ 2.1. Museums } \\
\hline $\begin{array}{l}\text { Historical museum - } \\
\text { Theth; }\end{array}$ & 4.0 & 3.9 & 4.1 & 3.9 & 4.1 & 4.1 & 4.0 & 4.1 & 3.9 & 3.7 & 4.1 & 3.99 & $\mathbf{N}$ \\
\hline \multicolumn{14}{|l|}{$\begin{array}{l}\text { 3.ETHNO-SOCIAL } \\
\text { MOTIVES }\end{array}$} \\
\hline \multicolumn{14}{|l|}{$\begin{array}{l}\text { 3.1. NATIONAL } \\
\text { DRESS }\end{array}$} \\
\hline $\begin{array}{l}\text { National dress in } \\
\text { Kelmend, Vermosh }\end{array}$ & 2.6 & 4.1 & 2.9 & 4.4 & 4.2 & 4.3 & 3.8 & 4.1 & 2.3 & 2.6 & 3.8 & 3.55 & $\mathbf{N}$ \\
\hline
\end{tabular}




\begin{tabular}{|c|c|c|c|c|c|c|c|c|c|c|c|c|c|}
\hline and Theth & & & & & & & & & & & & & \\
\hline $\begin{array}{l}\text { 3.2.FOLK SONGS } \\
\text { AND GAMES } \\
\end{array}$ & & & & & & & & & & & & & \\
\hline 3.2.1.national games & & & & & & & & & & & & & \\
\hline $\begin{array}{c}\text { Folk songs and } \\
\text { games in walley of } \\
\text { Theth } \\
\end{array}$ & 3.1 & 4.4 & 3.6 & 4.2 & 4.2 & 3.6 & 3.9 & 4.0 & 3.7 & 3.6 & 3.7 & 3.82 & $\mathbf{N}$ \\
\hline 3.3.CULINARY & & & & & & & & & & & & & \\
\hline $\begin{array}{l}\text { Ferliku (roasting } \\
\text { lamb) in walley of } \\
\text { Theth; }\end{array}$ & 1.9 & 4.3 & 3.6 & 4.1 & 3.9 & 3.9 & 3.9 & 3.9 & 3.7 & 4.0 & 3.7 & 3.72 & $\mathbf{N}$ \\
\hline 3.4. ARTIZANS & & & & & & & & & & & & & \\
\hline $\begin{array}{l}\text { decorative works in } \\
\text { valley ofTheth }\end{array}$ & 4.3 & 3.9 & 3.8 & 3.9 & 3.8 & 3.4 & 3.6 & 3.9 & 3.1 & 3.3 & 3.7 & 3.70 & $\mathbf{N}$ \\
\hline $\begin{array}{c}\text { 3.5.FOLK } \\
\text { CUSTOMS }\end{array}$ & & & & & & & & & & & & & \\
\hline Traditional wedding & 3.3 & 4.1 & 3.9 & 3.4 & 3.8 & 3.6 & 3.3 & 3.9 & 1.7 & 3.1 & 3.1 & 3.38 & $\mathbf{R}$ \\
\hline Hospitality. & 3.3 & 4.1 & 3.9 & 3.8 & 3.8 & 3.3 & 3.3 & 3.9 & 2.7 & 3.1 & 3.1 & 3.48 & $\mathbf{R}$ \\
\hline Way of life & 3.8 & 4.1 & 3.9 & 3.5 & 3.9 & 3.6 & 3.9 & 3.6 & 1.8 & 3.1 & 2.9 & 3.46 & $\mathbf{R}$ \\
\hline $\begin{array}{lr}\text { Averge } & \text { tourist } \\
\text { assessment of folk } \\
\text { customs }\end{array}$ & 3.5 & 4.1 & 3.9 & 3.6 & 3.8 & 3.5 & 3.5 & 3.8 & 2.1 & 3.1 & 3.0 & 3.44 & $R$ \\
\hline $\begin{array}{lr}\text { Averge } & \text { tourist } \\
\text { assessment } & \text { of } \\
\text { ethno-social motifs }\end{array}$ & 3.2 & 4.2 & 3.6 & 4.0 & 4.0 & 3.7 & 3.7 & 4.0 & 2.8 & 3.2 & 3.6 & 3.66 & $\mathbf{N}$ \\
\hline $\begin{array}{l}\text { GENERAL } \\
\text { ASSESSMENT OF } \\
\text { TOURIST OF } \\
\text { ANTROPOGEN } \\
\text { MOTIFES }\end{array}$ & $\begin{array}{c}3.3 \\
3\end{array}$ & $\begin{array}{c}3.8 \\
6\end{array}$ & $\begin{array}{c}3.8 \\
0\end{array}$ & $\begin{array}{c}3.8 \\
5\end{array}$ & $\begin{array}{c}3.9 \\
2\end{array}$ & $\begin{array}{c}4.0 \\
1\end{array}$ & $\begin{array}{c}3.8 \\
3\end{array}$ & $\begin{array}{c}3.9 \\
7\end{array}$ & $\begin{array}{c}3.3 \\
3\end{array}$ & $\begin{array}{c}3.6 \\
5\end{array}$ & $\begin{array}{c}3.8 \\
3\end{array}$ & 3.76 & $\mathbf{N}$ \\
\hline $\begin{array}{l}\text { GENERAL } \\
\text { ASSESSMENT OF } \\
\text { TOURIST OF ALL } \\
\text { TOURIST } \\
\text { MOTIVES }\end{array}$ & 2.5 & 4.0 & 4.1 & 4.1 & 4.1 & 3.0 & 4.0 & 4.0 & 3.5 & 3.8 & 3.9 & 3.74 & $\mathbf{N}$ \\
\hline
\end{tabular}

Based on the obtained values of the general, average/individual and total tourist value the motifs were classified in different hierarchical ranks: Local (L), Regional (R), National (N) and International (I), which represents, among other things, an important landmark for the establishment of priorities for the development of tourism in the future and incorporate valuable tourist motives in the tourism product (Kušen, E., 2000; Košić, K., 2011, 21).

Through the evaluation process we came to the result that all of the 29 identified tourist motives in the area of the Theth Valley evaluated by the total value of tourism 3.74 and rightly it can be considered a valuable tourist resource. The biggest tourist value have these parameters: ambience motives (rating 4.15), landmark motif (4.13), uniqueness motif (4.10), and the lowest parameter Geographical-tourist location position and transport availability motifs (rating 2.55). 
A large number of the most valuable tourist motives in the Theth Valley confirms the high quality of motif of its value, which represents the basic condition for the development of tourism in this very promising tourist region. In the following, we will show the most valuable natural and anthropogenic tourist motifs, which will best depict touristic value of the Theth Valley.

\section{Bosh's Peak}

Bosh's Peak is located on the touristic-geographical region of Albania's Cursed Mountain, on the left side of the Theth Valley. It's touristic and geographical position and transport links are not favorable. General tourist value of this peak is 3.58 and is ranked in the group of motives of national tourist interest. The biggest tourist value has parameter of ambience motives (rating 4.60), and the lowest parameter has touristgeographical position and transport links of the motives (rating 1.00).

This peak is one of the craggiest, most impressive, the most unique and most attractive mountain peaks in the area of the Cursed Mountains. Its height is $2416 \mathrm{~m}$ above sea level. Since it is fully visible from the south, where the terrains are below sea level, one gets impression of a high altitude, which is why the people of this region calls it "the roof of the Cursed Mountain" (Gruda Gj., 1991, 74). Bosh's Peak makes hydrographic junction that feeds water several rivers: Theth, Šalje (Shala), Valjbone (Valbona) and others.

Bosh's Peak is complementary tourist motive (rating complementarity 4,10), which has excellent conditions year-round use for tourism, together with tourist motifs that are in its vicinity: Harap's Peak (Maja e Harapit/Harapov vrh), Peja's Gorge (Qafa e Pejes), the Theth Valley, Theth river, waterfall Grunasi and others.

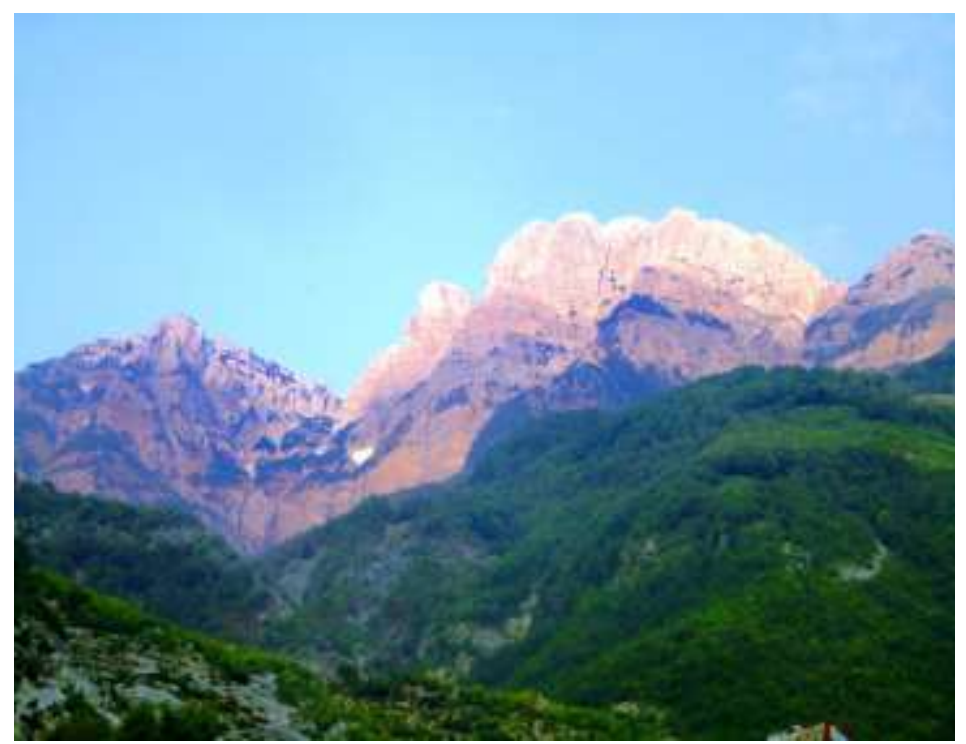

Fig. 1. View of the Bosh's Peak (Photo by Q. Kastrati, 2014.) 
This peak has good conditions for tourism and recreation, hiking, camping, hunting, and so on. To use Bosh's Peak for tourist purpose it is necessary to build traffic and tourism infrastructure (roads, marked hiking trails, equipment and infrastructure for accomodation and tourist activities, etc.). Access to the Peak is relatively favorable compared to other most valuable peaks of the Cursed Mountains and the most convenient access is through the road Skadar-Koplik-Boge-Theth, which is $70 \mathrm{~km}$ long.

\section{Theth Valley}

Theth Valley is located in the northern part of touristic-geographic region of Albania northeast of Shkodra (Skadar) at about $70 \mathrm{~km}$ away (to Boga pass the asphalt road, then gravel road to Theth). Naturally it is well accessed from Valbona gorge and the valley of the river Shala (Šalja) and lakes of Jezer, and communication as we have already pointed out, the road to Boga (Boge), Koplik and Shkodra (Skadar), a distance of about $70 \mathrm{~km}$.

Through the tourist and geographical evaluation procedure we found that Theth Valley has an overall tourism value of 4.30 and is ranked in the motives of national tourist interest. The highest tourist values have these parameters; attractiveness, ambiece, uniqueness, possibility to exploit motives for tourist purposes, the degree of preservation and compatibility with other tourist motives (rating 5.00), while the least touristic value has a parameter of tourist-geographical location and transport links(rating 1.70).

The direction of Theth Valley is N-S, starting from the spring Okolija to the river Shala (Šalja) in a distance of about $15 \mathrm{~km}$. Valley in the central part is broad about $150 \mathrm{~m}-$ 200m (Gruda Gj., 1991., 41). From the spring of Okolija to the river Shala (Šalja) is characterized by a number of geomorphological (canyons, gorges, surfaces), hydrological (springs, waterfalls and cascades), endemic and endemorelict species of flora and fauna, etc., which are located in the valley, and making it complex tourist motive of high tourist value (rating 4.30). Theth Valley has been proclaimed as a National Park on 21.11.1966 and covers an area of 2,630 hectares, with high natural, cultural, scientific and tourist values(Hoti M., 2011, 91).

According to its attractive, recreational, aesthetic and curious characteristics, Theth Valley, has excellent conditions for mass winter tourism, sightseeing and recreational tourism, hiking, hunting, health tourism etc., and an abundance of anthropogenic tourist motives (cultural heritage, ethnographic resources etc.) providing conditions so we can classify them into independent and complementary touristic motives.

\section{The site of a typical mountain climate: Theth Valley}

The site of a typical mountain climate: Theth Valley is located in the area of touristicgeographic region of Albania. It belongs to the mountain valley of typical mountain 
climate characteristics. Tourist-geographical location and transport availability is relatively favorable (1.90).

General tourist value of the site of a typical mountain climate is 4.29 and is ranked in the climate motives of national tourist interest. The largest single tourist value have these parametersattractiveness, ambience and level of preservation of the motives (rating 4.90), and the lowest parameter has the degree of utilization the motives for tourism purposes (rating 1.70).

The site of a typical mountain climate Theth Valley from 800 to $1950 \mathrm{~m}$ above sea levels covers an area of 2630 hectares. Latitude, altitude, closeness to the Adriatic Sea and exposure to it have given rise to the emergence of a very specific climate varieties of mountain climate of mountain climate, modified under the powerful influence of the Adriatic Sea, that reach to the Theth Valley thkoji do doline Theth through the valley of the river Shala (Šalja). At this location of mountain climate, summers are fresh with an average annual temperature $10^{\circ} \mathrm{C}$, the January air temperature $-1{ }^{\circ} \mathrm{C}$ and the July of about $19^{\circ} \mathrm{C}$ (Hoti M., 2011, 91-93).These data on air temperatures show that the area is directly influenced by the flow of warm and humid air masses from the Adriatic Sea, which through the valley of the river Shala (Šalja) reach the Theth Valley.

Rainfall is very abundant and it is considered that this valley is one of those with the highest rainfall in Albania (over $3000 \mathrm{~mm}$ per year). Snowfall, which usually fall in the coldest months of the year (about 100 days), forming a thick layer of snow around $150 \mathrm{~cm}$ (Imeraj P., 2009, 19) and the mountain slopes of the northeast exposure are very favorable conditions for the development of winter tourism. Also, a combination of climatic elements in the summer period are very beneficial to a variety of tourist activities on this site, such as mass recreation, camping, hiking, tours and so on.

\section{Waterfall Grunasi}

Waterfall Grunasi is located in the area of touristic-geographic region of the Cursed Mountains in Albania on the left side of Theth Valley. Tourist-geographical location and transport links are relatively good (rating 2.20). This waterfall is one of the largest and most beautiful in Albania and a real tourist attraction. The waterfall is high around $30 \mathrm{~m}$, and is located in a landscape of primeval beauty and extraordinary biodiversity, which is dominated by spruce and fir and beech-fir forests, aromatic and healing herbs and a large number of endemic and rare species of flora and fauna.

Through the process of the tourist evaluation we found that overall tourism value of the hydrographic motive is 4.26 and is ranked at the motives of national tourist interest. The largest single tourist value has the parameter of the attractiveness of the motive (ranking 5.00), and the lowest parameter has tourist-geographical location and transport links motives (ranking 2.20). From tourist-geographical point of view it is important to emphasize that this hydrographic tourist motive has a very high level of attractiveness, uniqueness and extraordinary beauty. 


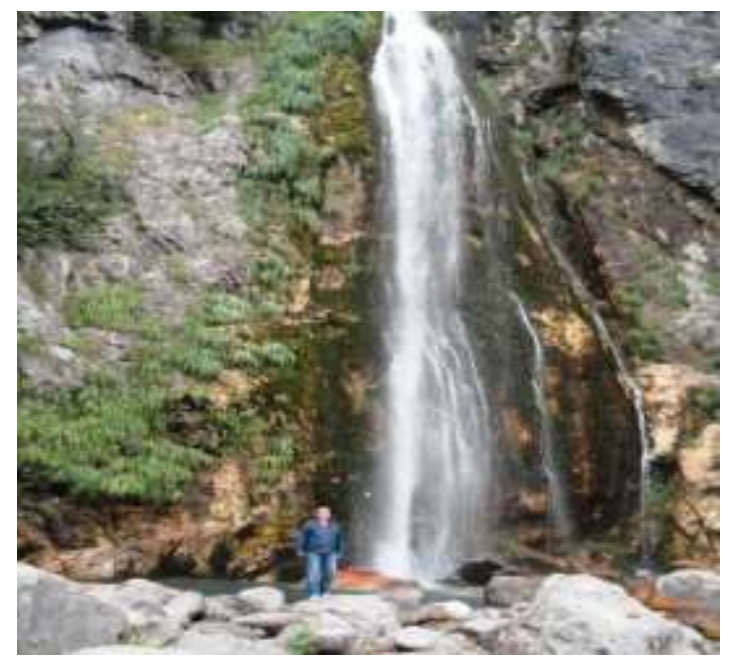

Fig. 2. Waterfall Grunasi (Photo by Q. Kastrati, 2013.)

\section{Location of typical mountain biogeographic characteristics: Theth Valley}

Location of typical mountain biogeographic characteristics: Theth Valley, is located in the area of touristic-geographic region of the Cursed Mountains in Albania. Touristgeographic position and transport links are not good (rating 1.90), because of its peripheral position in relation to the large urban centers and away from the roads, but close to the biogeographical site is a large number of very valuable natural tourist motives. This site of biogeographical Alpine characteristics in terms of motive is valued with the general tourist value of 3.55 and is ranked in the motives of national tourist interest. The highest single tourist value has the parameter of the ambience motives (rating 4.60), and the lowest of tourist value has the parameterdegree of utilization for tourist purposes (rating 1.70). Theth Valley was declared a National Park in 1966 (Hoti M., 2011, 91), in this area is a large number of habitat, mainly: beech, conifers, aromatic, medicinal and edible plants, and a large number of wild animals of great importance for the development of tourism. It is estimated that the Valley of Theth has 1,650 species of plants (Karta Ekot.,PKTH 2004), of which a large number of endemics (4 types) and sub-endemics (16 types). Beech forest (Fagus sylvatica) occupies a large area in the Theth Valley at altitudes of $700 \mathrm{~m}$ to $1900 \mathrm{~m}$, but the vegetation border closes bark Pine (Pinus heldreichii), which rises to $2200 \mathrm{~m}$ above sea level. The higher of the belt stretch alpine pastures that are rich with aromatic and medicinal herbs. In addition to these types of flora in Theth Valley, there are Wulfenia baldacci Deeg. (Solar plants alb.), Lilium albanicum (Albanian lily), Campanula Scheuchezeri (sound flowers), Viola of Dukagjini (Dukagjini flowers), Gentiana lutea called after Illyrian King (Hoti M., 2011, 94). Of species of wildlife in this area live 26 species of mammals and 45 species of birds, such as chamois (Rupicapra rupicapra), roe deer (capreolus capreolus), brown bear (Ursus arctos), wild boar (Sus scrofa), Lynx (Lynx lynx) hare and so on., (Hoti M., 2011, 94), which here have excellent conditions they have a quiet refuge, 
overgrown trees and enough water. Of fish is known trout living in the river of Theth. Often is located in the Valley of Theth, especially near the river bed on the southern part we find even the Mediterranean flora elements such as figs, grapes and others.

This site full of biogeographical characteristics of virgin forests, has attractive, aesthetic and curious features, and as a biogeographical tourist in a typical mountain climate and biogreographical characteristics, can be included into complementary tourist motive, with other natural tourist motifs that are found in the vicinity. This can have a special meaning that is to activate the biogeographical motives in defining the tourism offer. Theth Valley is a site of typical mountain and biogeogrpahic characteristics is the most attractive and the most famous area of the Albanian tourist region of the Cursed Mountain, rare (endemic and relict) species, aesthetic and curious biocenosis characteristics and a large number of attractive species for hunting and fishing.

The configuration of the terrain, geomorphological tourist motifs, climatic and hydrogeographic conditions, rich and diverse flora and fauna create good conditions for development of winter mountain, recreation, hunting and fishing, eco-tourism, weekend, scientific and eco-tourism. Possibilities of this site for tourism purposes for now are limited, due to the lack of transport and tourist infrastructure.

\section{Tower of detention in Theth}

Tower of Detention (Kulla e Ngujimit-Theth) is located in the southern part of the village Theth, on the left bank of the eponymous river, near the Waterfall Grunasi. Through the process of valorization we found that Tower of Detention has high tourist value (rating 3.79) and ranked in the motives of national tourist interest. The largest single tourist value has a parameter of tourist attractions motifs (rating 4.80), and the lowest tourist value has a parameter of tourist geographical location and transport availability motifs (rating 1.90).

The Tower is a house of type tower and has three floors, it was built about 400 years ago (according to the story of Sokola Koçeku, heir to thefamily and guide in thetower). The tower is in good condition for visitors, but should be put up a little better for the visit of foreign tourists who are present in large numbers in Theth, throughout the year. The owner of the tower, Mr. Koçeku, tells us that in the Tower of Detention (Kuli Zatočenja) occured many settling, revenge and blood feud between the clans and the inhabitants of this region. The abovementioned settlement were carried out by the beginning of the Twentieth century, when the leaders of the clans that the old man (the man who has settled people) took bribes, and since that time in this Tower were not allowed any settlement, but this Tower was used for housing and other towers in the area of the Cursed Mountaines. Tower of Detention is built on three floors, internally connected by wooden stairs. The whole Tower is built of stone. The ground was a space used for horses and storage, and upstairs are rooms for the couch, sit-ins, sleeping and dining. On the walls thick more than one meter are loopholes. 


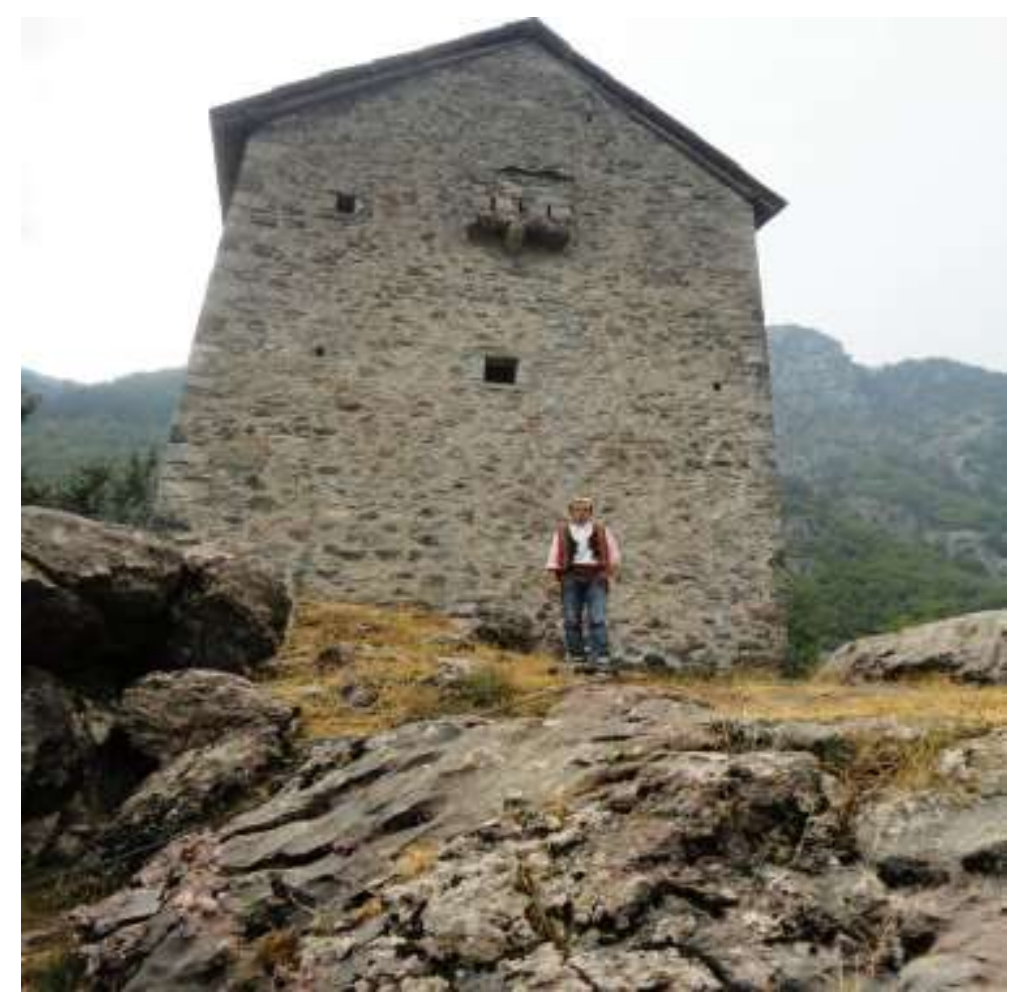

Fig. 3. Tower of Detention - Theth (Photo by Q. Kastrati, 2014.)

In the Tower are now placed traditional handicrafts and products made of wool, wood and others. Tower of Detention is a very important cultural and historical motiv which attracts large number of tourists, is open to visitors (tourists) every day, it has a guide presenting the history and cultural product within the tower, in order to create a single entity to tourist and complete experience during their stay in the Tower. According to its architectural, unique, attractive and aesthetic characteristics, the Tower of Detention can be classified as a complementary tourist motive, with the numerous and important tourist motives of high level in their surroundings such as a large number of mountain peaks, passes, slopes, mountain climate more favorable to the duration of the snow cover, water sources of Okolija, river Theth, waterfall Grunasi, a large number of endemic species of flora and fauna, and anthropogenic tourist motifs (culturalhistorical, artistic and ethno-social), and is likely to attract even more foreign and especially local clientele.

\section{CONCLUSION}

Theth Valley has an area of $124 \mathrm{~km}^{2}$, or 4.24 , tourist motives per $\mathrm{km}^{2}$. In this area of the specific gographical and historical pecuilarities, there are many and varied tourist values, which is extemely important for the tourist-geographic aspect, and taking into account that this is a great wealth of very valuable, both natural and anthropogenic 
motives. In the area of Theth Valley are 29 tourist motifs with higher tourist rating, such as: Bosh's Peak (Bošov vrh) (3.58), Theth Valley (4.30), Waterfall Grunasi (4.26), Tower of Detention (3.79) significance have great importance for the development and promotion of cultural and scientitific activities. Tourist evaluation shows that all analyzed values of art tourist motives of the Cursed Mountains have a national significance with high value for tourism and geographical tourism, uniqueness, attractiveness, artistic value, attractions, buildings and equipment, the possibility of using motives for tourism purposes, etc.

To be able to talk about the development of tourism in this area is necessary to adopt legislation that would stimulate investment and maintenance of existing art tourist motives then it would be possible to create a cultural tourism destination.

\section{REFERENCES}

1. Gruda Gj. (1991): „Gjeografia fizike e Shqipërisë“, Akademia e Shkencave e RPS të Shqipërisë, Vëllimi i dytë, Qendra e studimeve Gjeografike, II, Tiranë;

2. Hoti M. (2011): Mundësitë e zvillimit të qëndrueshëm -rasti i Parkut Kombëtar Theth Studime Albanologjike, IV, Tiranë;

3. Imeraj P. (1997): Parku Kombëtar Theth, Shoqata "Ruajtja e Pyjeve dhe Mjedisi Gjelbër”, Preservation of Forests and Green Environments"PFGEA, Shkodër

4. Kušen E. (2001): Turizam i prostor, Klasifikacija turističkih atrakcija, Prostor, No 9/2001, Institut za Turizam, Zagreb, 1-21;

5. Košić K. (2011): Turistička valorizacija-pojam, cilj, elementi, Prirodnomatematički fakultheth Univerziteta u Novom Sadu, Novi Sad, 7. URL: http://www.dgt.unsa.ac.rs/ download/otrl.pdf; 